\title{
După coada oilor: long-distance transhumance and its survival in Romania
}

\author{
Caroline Juler
}

\begin{abstract}
Long-distance transhumance still exists in Romania, but is becoming increasingly rare. This article gives some of the reasons why the phenomenon arose, why it has survived for so long and what are the main threats to its continuation. It attempts to show how deeply ingrained pastoralism is in Romanian culture. After giving a historical and geographical perspective on the practice, the article focusses on four transhumant families from an area which is famous for its shepherding skills. The area's name is Mărginimea Sibiului and it lies in the southern Carpathian Mountains. One family from the village of Jina is singled out for particular attention. The article looks at how this family manages its sheep, its hired shepherds and its journeys between seasonal pastures. It assesses the economic viability of sheep farming in Romania and the pros and cons of walking sheep over long distances, outlining some of the social, cultural and environmental benefits which would be lost if transhumance were no longer practised.
\end{abstract}

Keywords: European agricultural policy; CAP; European wild carnivores; Shepherding; Carpathian mountains

\section{Background}

După coada oilor, or 'going on the road', is a term that Romanian sheep farmers and hired shepherds use to describe long-distance walks with their flocks between summer and winter pastures. 'Long distance' here may mean anything from 50 to $300 \mathrm{~km}$ and periods of between two days to eight weeks. It may also have meant driving sheep to market, but this was not the prime reason for making such journeys.

Possibly originating in the Mesolithic period (Nandriş 1985; Arnold and Greenfield 2006) and once practised across Europe, these seasonal livestock movements are technically known as transhumance. Evidence for the existence of shepherding during the Dacian period (c. $500 \mathrm{BC}$ to $106 \mathrm{AD}$ ) comes with the find of a pair of sheep shears in the Cindrel range of the southern Carpathians, and the ancient Romans rented land to shepherds in the same area (Grecu 1990, p. 141). Totoianu (2010) considers that long-distance transhumance in what is now Romania could not have begun before the fourteenth century. Documents relating to the transhumance of 'Vlach' (in other words, Transylvanian) flocks from the southern Carpathians to the Beskid Mountains of Moravia and Poland show that that particular route was well known in the

Correspondence: caz@mamaliga.co.uk

Droifa, Brynberian, Crymych, Pembrokeshire SA41 3TG, Wales, UK fourteenth century. This suggests that it could have been in use a lot longer (Carpathian Sheep Transhumance 2013, personal communications).

Long-distance transhumance is still practised in the Romanian region of Transylvania. Treks between summer and winter pastures can cover distances of up to $300 \mathrm{~km}$ and take up to six weeks in one direction. But as life becomes harder for Romania's transhumant herdsmen, shortdistance transhumance between the farmers' homes and their mountain pastures (avoiding main roads and built-up areas) is becoming much more common (Huband et al. 2010). In Romania this is called pendulare (pendulation). Short-distance transhumance is similar to the Swiss 'alp system' described by Luick (2008), and according to Huband et al. (2010), it has a more promising future than the longer sheep walks, since so many families still rely on exploiting the summer pastures for their own food.

\section{Viability of sheep farming}

Raising sheep is an important source of income. With an estimated 11 million breeding ewes, Romania has the third largest flock of all the 27 European Union (EU) member states (Spain has the largest, with 15 million breeding ewes). Its national flock bucked the EU trend in 2007 to 2008 by growing by $5.45 \%$ (Hybu Cig Cymru Meat Production Wales 2008). In 2011, Romania had just over $10 \%$ of the 
sheep in the EU (Eurostats 2012). Although wool is virtually valueless, sheep's cheese is highly significant, accounting for half or more of the earnings made by the farmers studied in this article. And according to de Rancourt and Carrère (2011, p. 108), 'Romania... could rapidly become the European leader in sheep milk production.'

Although roughly half of all Romania's sheep are kept for milk (turned into cheese) rather than meat, in 2008, sheep contributed $6 \%$ of the EU's total lamb and mutton production (a decline of $13 \%$ on the previous year) as compared with the UK's 34\% (Hybu Cig Cymru Meat Production Wales 2008). According to Ilişiu et al. (2013), 'in the past 16 years, Romania was ranked first place in Europe regarding live animals exported for slaughter. In 2004 the maximum number of exported animals exceeded two million... Over $97 \%$ of the volume of exports is made up of... Turcana [lambs] and the difference of $3 \%$ is comprised of ... Tsigai [lambs]... The main destination of these exports is the West European countries (Italy, Spain), and Muslim countries (Saudi Arabia, Libya)'.

Leaving aside the welfare issues of live export, most of Romania's sheep farms are not - yet - massive agribusinesses. And they play a vital role in maintaining biodiversity: 'In Romania, small-scale... farmers own $70 \%$ of the national sheep flock and play a vital role in maintaining large tracts of valuable semi-natural habitats.' (PASTORAL 2 2001).

\section{Industrialisation versus pastoralism}

Compared to Britain, Romania was a latecomer to industrialisation. The greatest drive towards heavy industry came during the Ceaușescu Communist regime (1965 to 1989), but it is still an agricultural country. European Union statistics show the percentage contribution of agriculture to Romania's overall gross domestic product (GDP) to be more than $3.5 \%$, and therefore one of the highest. On the other hand, the average density of livestock grazing in Romania is one of the lowest in the EU. Figures given by the Eurostat Statistical Atlas show $<0.60$ livestock unit (LSU) per hectare of fodder area in Transylvania, the Banat and north-west Romania, and between 0.60 to $0.90 \mathrm{LSU}$ per hectare of fodder area in the eastern Romanian regions of Moldavia and Wallachia. One LSU is equivalent to one cow or six medium-sized sheep! (Europe Regional Yearbook 2013).

Pearson (2012, p. 139) puts the case more strongly. Quoting the Romanian Center for European Policies, he says: '...agriculture is one of the most important economic sectors in Romania. This sector generates $12 \%$ of the country's GDP and around 30\% of Romania's active population works in agriculture. Most of agricultural labour force is active in semi-subsistence farms, with little connection with the market. The development of agriculture is hampered by one of the worst rural infrastructures in Europe and by an extremely fragmented ownership system. Semi-subsistence farmers own small pieces of land with an average size of 1.5 hectares. Any decision on CAP [Common Agriculture Policy] reform made in Brussels will have a dramatic impact on Romania's economic and social landscape'.

Between 1949 and 1962, land in accessible areas was collectivised, but this left a sizeable proportion out of collective or state arm ownership. The historian Deletant (2010) points out that 'Collectivization was completed in 1962, and its results put 60 percent of the total area of fifteen million hectares of agricultural land in collective farms, 30 percent in state farms, and left 9 percent in private hands. The latter consisted of upland where inaccessibility made it impractical to collectivize.'

Romania's current land surface area - unchanged since 1962 - is $239,000 \mathrm{~km}^{2}$. One third of this is mountainous. According to Huband et al. (2010, p. 57), 'nationally there are an estimated 2.4 million hectares of semi-natural grasslands... and one source estimates 1.2 million hectares of semi-natural pastures and hay meadow habitats in the mountains.' As defined by Huband et al. (2010, p. 56), semi-natural grasslands are those 'dominated by unsown native plant species that rely on human activities to maintain the condition of the swards and prevent the establishment of shrubs or woodland.'

Collectivisation and the state farm system lasted until 1991. As Deletant (2010) notes, collectivisation took 13 years to complete, and met with widespread resistance in what was an overwhelmingly peasant society. 'Communist Romania's plans to industrialize from an agricultural base required not only massive financial investment, including foreign loans, but also a major readjustment of labour resources, involving movement from the land to the factory. The measures included the combination of agriculture with manufacturing industries and the gradual abolition of the distinction between town and country through a more equable distribution of the population over the country. [T] his plan... was termed by Ceauşescu "systematization." The proportion of the country's urban population rose from 22 percent in 1948 to 30 percent in 1965 and to 49 percent in 1983, and was projected in 1988 to rise to 75 percent in the year 2000 . The number of towns with populations ranging from under 3,000 to 320,000 rose from 152 in 1948 to 236 in 1978.'

Deletant ends his review with a quote that is highly relevant to the attitudes which policy-makers take towards sheep farmers and shepherds: "seven million peasants, who barely reach subsistence levels, have no idea of the difference between the political right and left, and buy on average a single toothbrush in a lifetime, pose a development problem not just for Romania, but for the European Union [EU] in general. It is hard to believe that by the 
twenty-first century the peasant problem in Romania has not only remained unsolved, it had actually been recreated close to its historical original, in spite of the efforts to eliminate rural underdevelopment"... Had the majority of EU leaders not dismissed views of Mungiu-Pippidi and other leading analysts of Romania, it is hard to believe that they would have so blithely accepted that Romania was ready in January 2007 for entry into the EU.' (Deletant 2010).

Despite this withering comment, Romania is in the EU. It also possesses one of Europe's rarest natural environments, one that is to a large extent dependent on traditional, low-impact agriculture - including transhumance, and one that is a 'blueprint' for many more industrialised nations (Akeroyd 2007). Akeroyd also notes that:

This is a landscape that Europe has mostly lost, where a wealth of plants and animals thrives alongside traditional agriculture. And there is no reason why its people should not have a happy and secure future, forging new prosperity in this ancient and productive landscape (2006, p. 9).

In February 1991, Romania passed a land restitution law (Verdery 1994). Many people who owned land privately before 1949 gained the right to get some of it back again. This has increased the numbers of small landholdings which form Romania's social and economic backbone. EU Agriculture Commissioner, and former Romanian Agricultural Minister, Dacian Cioloş, has written that 'Farmers should not be considered only as running food production enterprises. They act within a living environment that offers not only food and raw materials but an enriched public life. In other words, European agriculture has to be multifunctional: competitive not only for the market but also for citizens, as an economic activity that uses and manages renewable resources of public interest' (Pearson 2012, p. 278).

In the past 20 years, many of the open expanses formerly owned by state and cooperative farms have been enclosed together with open areas of mountain pasture. The new owners may be settled farmers, factories or property speculators, but urban sprawl and fences make it more difficult to move animals across country on foot. As older people die, subsistence farms, many of which lie in the mountains, are disappearing. But as Luke Dale-Harris (2014) points out in The Guardian newspaper, 'Meanwhile, the rural population is growing. Each year more than 100,000 people move back to the countryside from Romania's cities, where prices are rising but jobs are scarce and poorly paid.'

Barriers to long-distance sheep walks include road building and hostility from landowners, hunters and police. Well-meaning animal welfare, registration and hygiene regulations also make it harder for poor, small farmers to continue with their traditional way of life. Despite changes to the Common Agricultural Policy, it is contended that EU policy-makers do not understand the vital role that small farmers can play (Pearson 2012).

\section{Shepherding in Romanian folklore}

Romania's folk culture is full of tales about shepherds. The country's most famous myth of origin, Miorița, tells the story of a good shepherd who lets himself be murdered by jealous rivals after being warned of their plan by a talking lamb. Miorița is sometimes seen as a symbol of Christian magnanimity, Christ's martyrdom and turning the other cheek. Sandwiched between the Romanian Catholic west, the Muslim east, with Slavophone Bulgaria and Serbia to the south and Ukraine to the north, Romania is a predominantly Orthodox Christian country with a Latinbased language that traces its religious roots back to the Byzantine Empire. The cultural links between pastoralism and Christianity are too well known to need emphasising, but it is perhaps worth saying that in areas where shepherding has been important, churches and wayside shrines often contain murals or sculptures incorporating images of sheep.

Popular Romanian sayings and folk songs show sheep as sacred as well as useful animals. Mihai Coman (1996, p. 21) quotes the following:

The sheep is a holy animal; anyone who keeps sheep and bees will be lucky in everything they do. When there are no more sheep or bees, it will be the end of the world.

The sheep is a blessing, for as long as she lives, she sweetens and feeds you, and if she dies, her fleece warms you.

Because of their knowledge of mountains, shepherds were also used as messengers and spies in times of war.

If the foothills are included, the Carpathian Mountains cover two thirds of Romania's surface area. The mountains form a natural fortress enclosing the Transylvanian plateau, which until 1918 was physically and politically independent from the rest of the country. To give a brief history from c. 1100, Transylvania formed part of the Hungarian and later the Habsburg empire, while Moldavia and Wallachia, the two other main medieval areas of what is now Romania, were semi-independent principalities closely allied to the Byzantine Empire. But after the fall of Constantinople in 1453, they were forced to pay tribute to the Ottoman Empire and later accept princes appointed by Istanbul - or as in Dobrogea, became part of it. Poland and Russia were other powerful neighbours that threatened Romanians' sovereignty, and raids by Crimean Tatars were common until 1717 (Boia 2001, pp. 11-27; Juler 2009, pp. 41-49, 306). 


\section{Methods}

This article is the result of several informal research trips, from 2007 to 2013, to collect and record material about the phenomenon of transhumance. Interviewees included practising Romanian sheep farmers and hired shepherds, the farmers' families, as well as historians, ethnographers and government officials. The original aim was to interview people descended from Romanian shepherds who had migrated to southern Russia and the Caucasus in the period 1880 to 1914 . Over the past seven years, material was gathered from a dozen individuals whose families had shepherding connections to Russia. The historical investigations developed in parallel with a study of present-day transhumance in Romania. Most of the material used here comes not only from personal communications and audio recordings but also from Romanian and English written sources.

\section{Study area}

One area in particular stands out in connection with pastoralism and transhumance. It is called Mărginimea Sibiului, and it lies in the southern Carpathians to the south of Sibiu city (Figure 1). Mărginimea Sibiului is traditionally associated with groups of ethnic Romanian smallholders who were forced out of their villages on the plateau and retreated into the mountains when the Saxons colonised Transylvania from the twelfth century. It was historically distinct from surrounding communities of ethnic Hungarians and 'Saxons' (an umbrella term for immigrants who came from several different regions of northern Europe, many of whom spoke German), and has retained a strong sense of cultural and racial separateness. Mărginimea Sibiului consists of 17 villages and one town, scattered over the northern slopes of the Cindrel range.

Of these communities, the higher-lying villages including Rod, Tilişca, Jina and Poiana Sibiului are known for their inhabitants' expertise in sheep rearing and their adventurousness as transhumants. As Transylvania's textile trade developed, some of the sheep farmers lost their land to the very weavers who were exploiting their wool, but flocks grew. This too forced the sheep farmers to look for pastures further afield. Between the early eighteenth and the mid-nineteenth century, flock sizes grew out of all recognition. In the village of Săliște for example, the number of sheep quadrupled between 1714-20, and in the early nineteenth century, around 100,000 to 150,000 head were recorded there (Grecu 1990, p. 144). Huband et al. (2010) have stated that the increase of cereal crops in the nineteenth and twentieth centuries took more of the land away from grazing, making it even harder for pastoralists to survive. In the highest mountains, it was too cold in the winter and there was not enough grazing or dry fodder to sustain them. Seasonal movement with the animals to other places made common sense.

\section{History of transhumance in and from present-day Romania} In Romania there were no officially designated sheep roads like British drovers' roads or Spanish cañadas. Instead, shepherds memorised the routes, and although the paths are being eroded by enclosures, roads and new building, this is still the case today. Landowners of the past were often glad of sheep to graze their stubble because the sheep's dung fertilised the soil, and when it came to crossing national boundaries, shepherds knew the mountain paths by which they could evade densely populated areas, and customs duties, if they applied. Luick (2008) describes a very similar situation in Germany:

The Southwest German transhumance relied upon rules and privileges for the wandering shepherds. Unlike in Provence or in Spain there never existed a special or coherent system of legally-established drove roads. The paths the transhumances took on their journey from the summer pastures to the various winter grazing areas can more be described as a system of spatial corridors. Whereas the actual passage of the flocks is generally allowed, the daily grazings have to be individually sanctioned by the particular community and in most cases shepherds are charged a rent depending on the size of the flock and/or the length of time on the communal territory. Over time a tradition evolved as shepherds used the same transhumance corridors and had contracts with the same municipalities every year. In the past shepherds could even gain a small revenue if they kept their sheep overnight in folds on arable fields.

Documents from the fourteenth century show that shepherds from Mărginimea Sibiului over-wintered their sheep in lower-lying areas across national borders, as far away as Moravia in the present-day Czech Republic (Figure 2). Other popular destinations were not only Dobrogea (on Romania's Black Sea coast and under Turkish rule until 1878) and Istanbul itself since the Turks prized Romanian sheep for their meat but also Bulgaria, Macedonia, Serbia and the Banat. From the sixteenth century, Carpathian shepherds could be found wandering, or transhuming, to southern Russia and the Crimean peninsula. They eventually made their ways to the Caucasus mountains, where some presumably settled.

The depth and pervasiveness of pastoralism in Romanian culture have given rise to some fanciful theories that the fire god Prometheus landed in the Carpathian, not the Caucasian, mountains (Densuşianu 1913) and that ancient Colchis, from which the mythological figure of Jason snatched the Golden Fleece, lay in eastern Romania and not Georgia. 


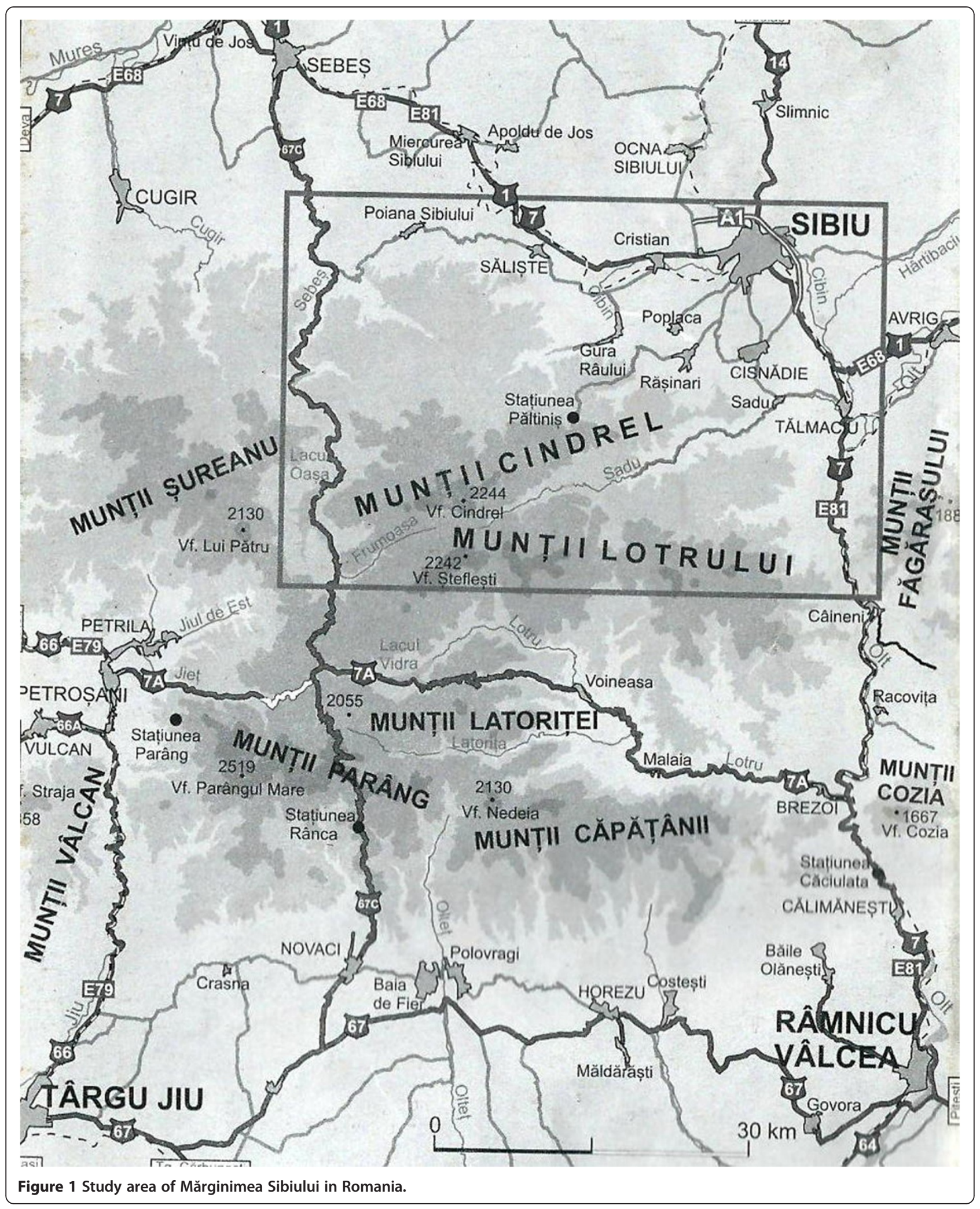

This study has found few historical records charting exactly how and why the earliest Romanian shepherds moved to the north of the Black Sea and the Caucasus (see Figure 2). And there are no signs that Transylvanian sheep walked home from southern Russia to Mărginimea Sibiului for the summer - it was too far. It is more likely 


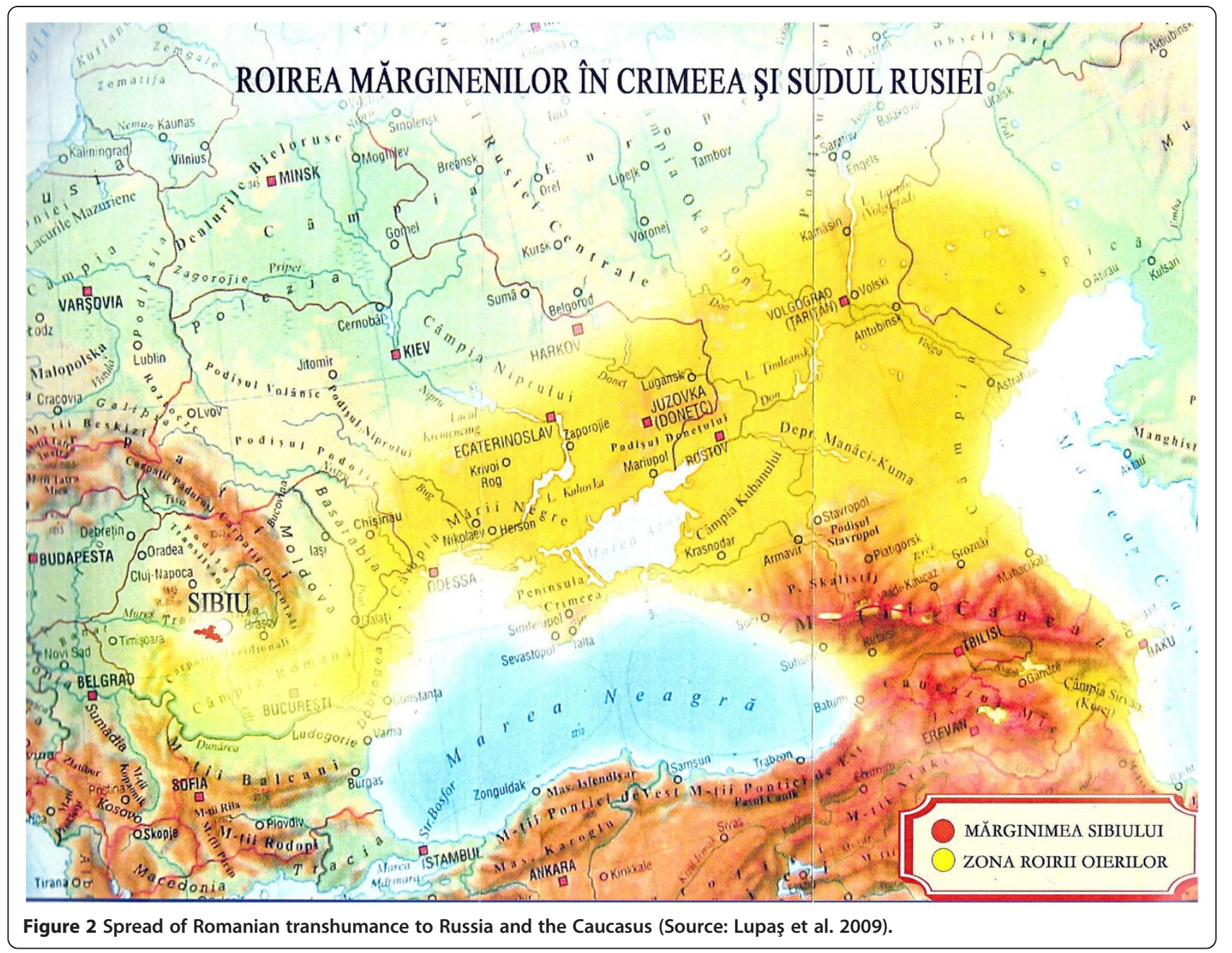

that the Mărgineni who established winter homes in Dobrogea migrated further east when the climate demanded or it was politically possible. Romanian shepherds would have been attracted to the vast expanses of grassland, especially as Russian peasants did not exploit them (Grecu 1990). Instead of returning home every year, a lot of Romanians moved eastwards, enjoying the milder climate which made transhumance unnecessary in winter. The political status of Moldavia, the eastern Romanian region part of which is now the Republic of Moldova, shows that it was, and still is, a halfway house between Romania and Russia: 70\% of Moldovans speak Romanian. But following the Tsarist purges of Caucasian peoples in the 1860s - and possibly because of them - another wave of migrations, starting from about 1880, brought Mărgineni shepherds to the recently vacated steppes of the Volga basin and to the east of the Black Sea. Using what may by now have been familiar paths, they established folds, and later farms, in Crimea and the Caucasus.

During this period, some of the Romanian settlers in the Crimea took their sheep to the Caucasus mountains for summer, establishing a new transhumant route to the east. There is no sign that they brought their animals home to the Carpathians on a seasonal basis. In many cases they abandoned the Turcana sheep for more commercially rewarding breeds such as Karakul and Merino, or cross-bred the Turcana with Merino to create the Tigaie sheep which, as mentioned above, has finer wool. It is certain that the Romanians themselves 'transhumed': they left their sheep in the hands of other family members or fellow Romanian shepherds while making occasional trips home to Mărginimea Sibiului to see their parents, wives or children.

There was a tradition that sons and nephews of the migrating shepherds would travel to Russia on their own when they reached 14 years of age and had finished school. Along with their adventurous spirit and educational achievements (Grecu 1990, p. 12), this facet of Romanian pastoralism has become a matter of pride in the annals of Mărginimea Sibiului (Lupaş et al. 2009). As Russia turned into the Soviet Union, and Stalin replaced Lenin, the plight of these Romanian sheep farmers became extremely 
precarious: some were killed or deported to Siberia, others starved, some disappeared and several scores escaped home to the Carpathians, minus their sheep.

During Communism, the upland villages Jina and Poiana Sibiului in the study area of Mărginimea Sibiului area were famous - if not notorious - for their wealthy sheep farmers. Some of these villages' farmers managed to earn steady incomes at times when most of the county was experiencing food and electricity shortages. Their luck was due to their remoteness, $1,000 \mathrm{~m}$ up in the mountains: they were not collectivised, they evaded certain taxes and the government guaranteed prices for their animals' milk, meat and wool. People who commuted to these villages from the poorer plateau below used to talk of 'going to America'.

\section{Transhumant shepherds: case studies}

Dan D is in his early thirties. He runs a flock of 1,000 Turcana ewes and rams which breed, on average, 500 lambs once a year. Turcana sheep are a shaggy, coarsefleeced, curly-horned, hardy, all-purpose breed (Figure 3), thought to be descended from the wild Mouflon (Ryder 1983, p. 23). During the Communist period, the Turcana virtually vanished in favour of the Tigaie (a cross between the Turcana and the Merino, bred for its finer fleece), and the Merino itself, but thanks to their ability to survive the harsh Carpathian winters, they have made a rapid comeback since 1989. Every spring and autumn, Dan walks the flock between his summer pastures in and above his home village of Jina, the highest in Mărginimea Sibiului (900 m), and his winter grazing grounds in Sălaj county, some $300 \mathrm{~km}$ to the north-west of his home.

It is still more economical for him to walk his animals between seasonal pastures than to send them by truck. Dan says that he prefers leading his animals on foot, because his sheep are healthier and more disease resistant due to the exercise they get and because they eat a wider variety of plants than they would if kept in one place all year round. He states that their meat and milk are of superior quality and taste better as a direct result of long-distance transhumance. Dan's faith in the health benefits of meat - and milk that come from extensive grazing is borne out by scientific evidence. The Pasture Fed Livestock Association (based in Britain) states on its website that 'Grass-fed meat tends to be lower in total fat and also has higher levels of "good fats" such as Omega 3. Milk and meat from grass-fed animals has higher vitamin levels - particularly vitamin E. Some studies also show higher mineral levels in grass-fed meat and milk.' (PFLA Pasture Fed Livestock Association 2011). Unfortunately, apart from the Slow Food Movement, which has Romanian centres in Bucharest, Braşov, Cluj and Turda (Slow Food Turda, n.d.), this study has found no equivalent Romanian or EU organisation that promotes meat and milk from animals that have been grazed extensively, or while on transhumance. The guaranteed prices for meat, milk and wool have vanished, and there is no Wool Marketing Board in Romania as there is in the UK.

In the weeks leading up to Romania's accession to the European Union (January 2007), it was widely believed that all forms of transhumance would be forbidden. In February, 2007 the Romanian Ministry of Agriculture published a news flash that was designed to clarify the situation (MAPDR 2007). After specifying the rules for vehicular transport, the article turned its attention to transhumance on foot. It stated that walking herds of animals 'should be avoided whenever possible because it leads to great loss of body weight and contagion'. It continued:

The displacement of the animals must be planned ahead so that it is carried out at a time when the weather is favourable, to avoid heavy rains, cold and also excessive heat. The route and resting points must be chosen by consulting local authorities, so that the animals do not come into contact with local beasts. Roads with heavy traffic must be avoided, in favour of side roads, but these side roads must be neither potholed nor covered in deep mud. Flocks and herds must be supervised properly, grouped by categories of sex and age, to a maximum number of... 500-600 sheep per flock. The movement must take place during the day, with a limit of... $25 \mathrm{kms}$ walking per day for sheep and goats. Sick or injured animals must not be moved... Similarly, females in the last month of gestation or the first month after giving birth, and young and aged animals must not be moved. Between May and October, fodder can be provided by pasture. If no pasture is available, two portions of corresponding feed and water must be provided, at least twice a day. The groups must be looked after by a sufficient number of well-trained herders. If animals die or need to be killed on the road, a veterinary officer must decide what action is to be taken.' (translated from Romanian).

As stated above, there are no officially designated sheep paths in Romania. In the autumn, Dan's animals have to make their way north, walking down through the woods and pastures of the Cindrel mountains towards the town of Sălişte, and across $200 \mathrm{~km}$ of the Transylvanian plateau before reaching their goal. This means crossing fast roads, fording rivers or finding bridges over them, walking over railway lines, and either skirting or passing through towns and villages. Their route goes past Cluj, the largest city in Transylvania, and several other conurbations including Turda and Ocna Mureș (Figure 4).

Questioned in 2010 about the dangers of transhumance, Dan said that the greatest threat came from people, not 


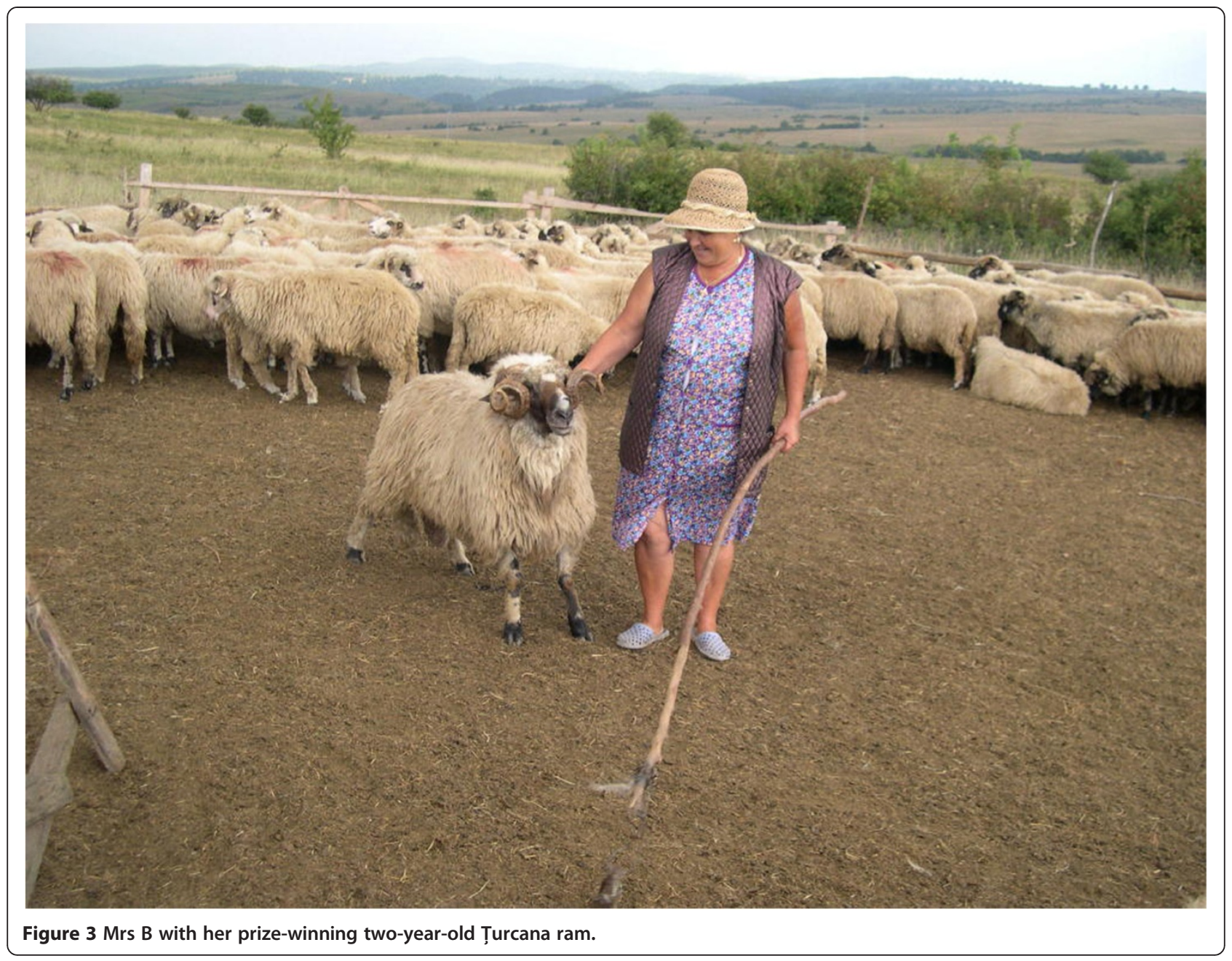

from wild animals. He remembers when he was a little boy that the way for sheep was much clearer than it is now. He blames land enclosures, hunters and hostile police. There is no law against walking one's sheep on transhumance per se, but only on the time of day, and the distance one may cover. This study has heard unconfirmed reports that some authorities demand a tax of up to 2,000 euros if one walks one's animals across county boundaries. ${ }^{\mathrm{a}}$

The farmers interviewed for this study say that sometimes they have to move their sheep at night so as to get safely through towns and across major roads, because that is when the traffic is lightest. Even so, sheep often get killed in road accidents, and while crossing railway lines. Dan has had several run-ins with policemen while attempting to get his flock across the E68, an international route that runs near Sibiu. Evasion is often better than confrontation. It is unsure whether he or other transhumant shepherds comply with the 600-head limit. If hired shepherds give notice - or disappear - at the last minute, flock masters can be left with an impossible situation. Dan has complained about another regulation, unverified here, that on the road, farmers must not use more than two dogs per thousand sheep. Dan said that this also makes life very difficult.

Dan owns a farmstead in the Sălaj village of Firminiş. He supplements his winter grazing by providing dried maize and hay, which he buys locally or in Jina village; he can bring it to Sălaj in his van or jeep, or by friends' transport.

Dan D bought the farm with 50 ha of adjacent grazing in 2010; before that, he rented various parcels of pasture from the local village or at another pastures, $18 \mathrm{~km}$ away. Today, he still rents grazing there as well as using his own. Dan's parents are also farmers, and during the 1970s and 1980s, both of them walked their sheep from Jina to the same over-wintering grounds, and back again in spring, leaving their other farm animals at home in the care of relations. Dan has four sisters, two of whom are older than him. His eldest sister also went on the road, as he did from the age of nine.

Huband et al. (2010) say that Jinari shepherds (i.e. sheep farmers from Jina) have traditionally chosen Sălaj for their 


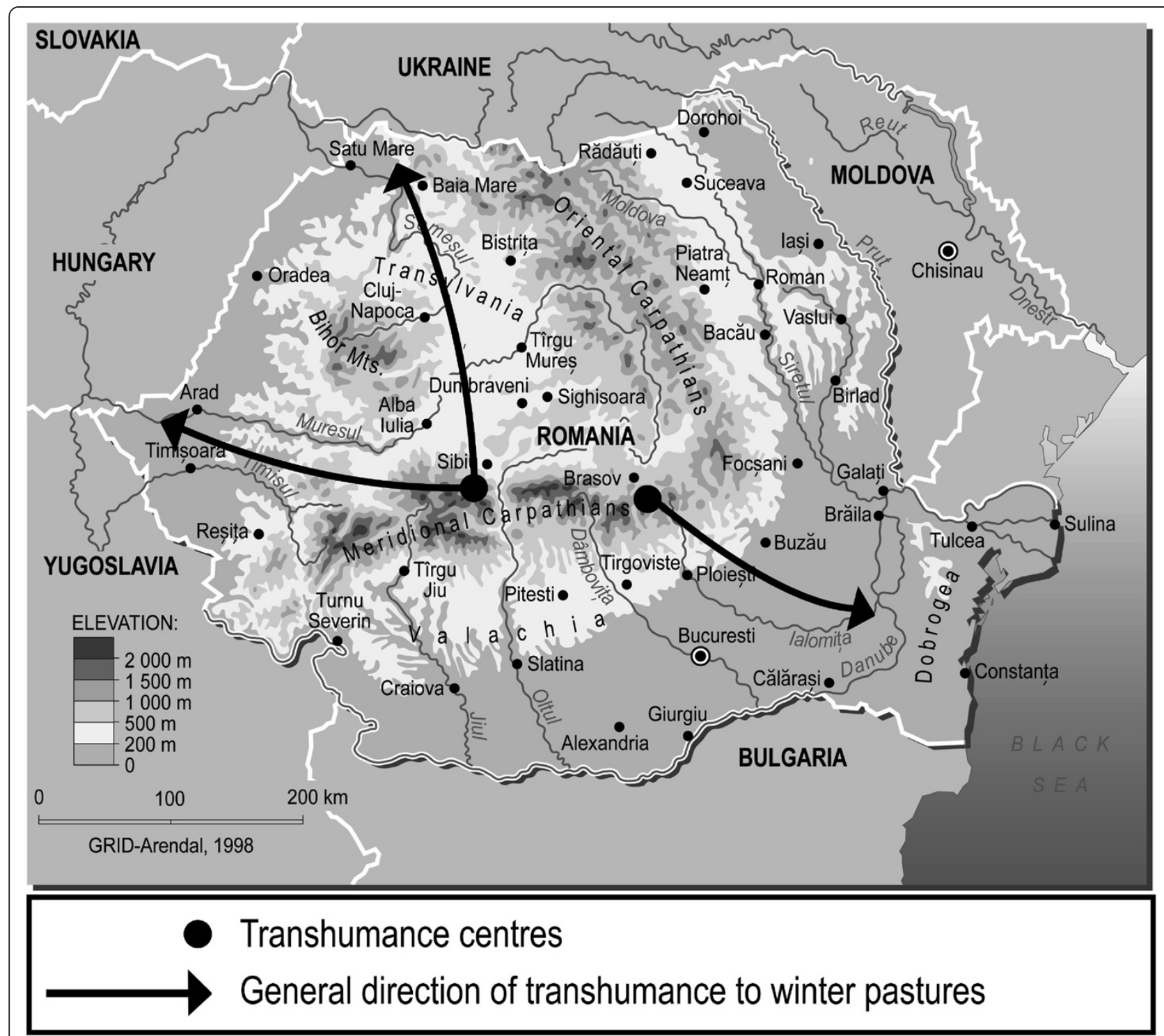

Figure 4 Transhumance centres and directions in present-day Romania (Huband et al. (2010)).

winter pastures. This study noted that four or five Jinari flocks were stationed near to Dan's during the winter of 2011/12. Sălaj lies in a corridor between the Apuseni mountains and the eastern Carpathians. It is several hundred metres lower than Jina, and the winters are usually mild enough there for the Turcana sheep to survive outdoors even in snow storms. The heaviest snow generally falls in December and January. Predominantly hilly, its landscape is a patchwork of open fields or strips designed for cereals, occasional fenced orchards, scrub and young woods that are mainly of beech and oak and which are managed by the county forestry service. Dan has made arrangements with the village councils (comune) and the forestry authorities which let his sheep cross village boundaries and graze in the woods.
Lambing takes place once a year and usually begins in February. In January 2013, with manual help from his hired shepherds and friends from Jina, Dan built a lambing shelter; previously, the ewes gave birth outside, although there was indoor shelter for vulnerable or sick animals.

In common with all sheep on rented winter pastures, Dan's flock has to get moving on or before 1 April. This helps to protect young crops from being trampled and eaten. If grazing is particularly short, or there are very young lambs, as in April 2012, which was preceded by two years of drought, he may walk his animals in a short circuit to strengthen them gradually before beginning the main journey (Figure 5). But owing to the time constraints, some sheep inevitably give birth on the road. Dan does not 


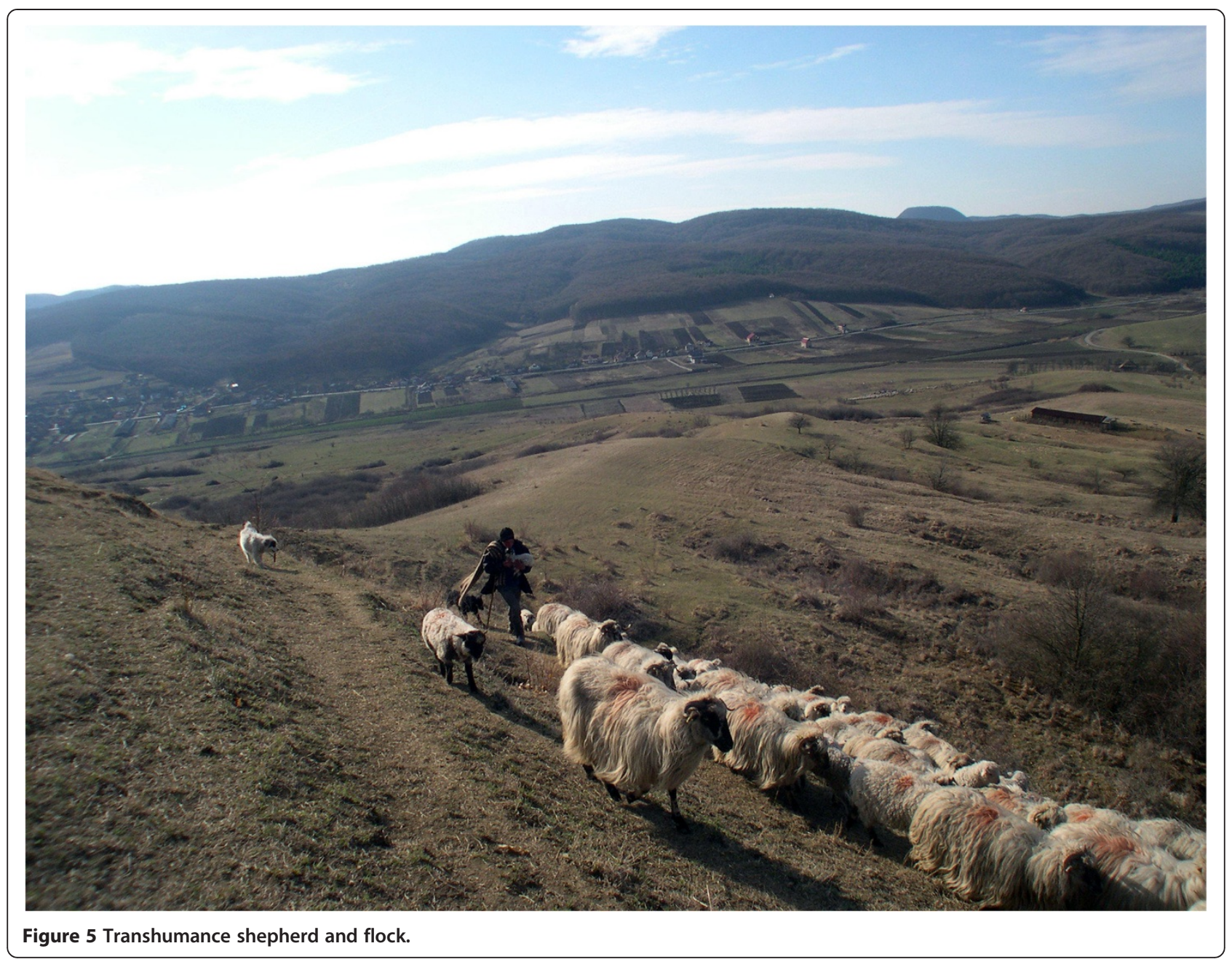

sell his lambs at Easter (when most lamb meat is sold to the internal Romanian market), but keeps his young stock until July or later, depending on whether he can get a good price for them. In any case the lambs are weaned in May as soon as they return home, and the mature sheep are shorn before heading to the higher pastures. Shearing (done manually) and bathing (October) require extra hands, and farming neighbours often fill the breach.

Dan's parents own a farmhouse in the centre of Jina. It has substantial outbuildings which house their hay, a couple of horses (used for traction), two or three pigs, and chickens, and a small garden where vegetables are grown for the household. The family also owns a 2-ha grădină, which is a fenced field about a kilometre from their house. The grădina yields two or three cuts of hay per year, and the sheep and the donkeys - which Dan uses to carry his team's camping gear while on transhumance - may be kept there for a week or two between summer and winter grazing. Even in the field that is close to the village, the sheep must be constantly overseen to protect them from wolves and bears.
Dan's mother occasionally sells surplus piglets at the annual animal fair at Poiana Sibiului, but otherwise sheep are their only commercial livestock. A cellar under the house contains the barrels of telemea (salted sheep's cheese) which provides the D family with half of its annual income (the rest comes from the sale of lambs and government grants). Dan receives an EU subvention per head of sheep for grazing his flock in a Less Favoured Area (LFA). Like the other farmers interviewed for this study, Dan says he could not manage without the EU funding.

There are no separate bedrooms in the family home: typically the parents, children and grandchildren share sofa beds in the sitting room and the adjacent 'clean room'. However, there is hot running water, a separate bathroom and a washing machine, the last item by no means usual in present-day Romanian villages. All the daughters and other family members help on the farm if they are needed and are physically able and free to do so. This often means spending time at one or other of the family's rented colibi (summer farms consisting 
of grazing land, log cabins and barns) when the sheep are grazing Jina's mountain pastures in the summer (between May and October). Dan needs two pastures because, as in winter, he separates his flock into two parts, keeping the sterpe (lambs and milkless ewes) with the rams in one group, and milking ewes in the other.

A 2007 report by a BBC correspondent was called 'EU clash with Romanian tradition'. It included an interview with another Jina sheep farmer. She said that her family made 'roughly 2,500 kilos of cheese a year. Ten kilos per sheep, in the milking months from May to October which they sell to the merchants for up to 10 New Lei (£2) a kilo' (Thorpe 2007). At the same rate, Dan's family would make about 7,000 kg a year

Dan's parents are in their early sixties. In summer, they live almost permanently at one of the lower colibi while Dan divides his time between the flocks, fetching supplies, milking and taking turns with the hired shepherds to do guard duty. He is also building a house for his new family; it stands next to his parents' home. Dan's wife also helps with the sheep and with cheesemaking, but she has a baby to look after, and, having expressed some dislike for life in the summer folds, it is uncertain how she will manage her time in future. The pigs and hens for the family are transported at the start and end of the season to and from the sheep folds by cart, jeep or on foot. Dan's father also helps with milking and cheesemaking. Although he no longer goes on the spring and autumn journeys, Dan's father takes part in summer and winter watches, and still sleeps in the open in summer.

Jina has about 60 working colibi; their number has reduced from roughly twice that amount during the past 40 years. Most are used for sheep but herds of cattle are kept too. A few Jinari own their summer farms, but most rent them from private individuals or companies. In 1991, Romania's government authorised the restitution of land that had been collectivised by the Communist regime in the 1940s. This meant that individual families could receive up to 50 ha of their former holdings and buy up to 200 ha. During the Communist period, Jina village owned more common grazing than any other village in Mărginimea Sibiului. The reasons for this date from the Habsburg regime (late seventeenth century until 1867) when the men of Jina agreed to defend the border between Transylvania and Wallachia which ran along the mountain ridges nearby. The village received several mountains as a reward.

Dan employs between two and five hired shepherds. He prefers to find shepherds by word of mouth; otherwise, like many Mărgineni farmers, he will look for new hands early on Monday mornings at Sibiu railway station. Each one gets a salary of between 200 and 300 euros a month, depending on their age and experience. As well as their salaries, the hired men are given their daily food, as well as clothing, alcohol and cigarettes. In return, they are expected to work and sleep outdoors for most of the year, no matter how bad the weather is (Figure 6).

The hired men must help with the daily milking, herding, feeding, treating and protecting the sheep. They have to stay with the flocks all day and sleep near them at night. They make their beds on the ground or in țoțe (boxes made of wood or corrugated iron which are just large enough to contain a man lying at full length) (Figure 7). Traditionally, at night or in bad weather, shepherds wear a long sheepskin cloak known as a cojoc or sărică, which has the fleece on the outside. Against the rain, they may have an oily woollen plaid called a tol, but many use plastic sheeting as a raincoat. Traditional headgear for Mărgineni shepherds consists of black, rimless, pot hats made of hard, felted material. The shepherds' footwear is usually a pair of halflength plastic Wellington boots, with felted or woven wraps instead of socks.

One of the longest-serving hired shepherds, Adam, has been with the D family for five years. He is 23 years old and an orphan. He comes from Sălaj, where Dan and his family have created a network of useful contacts. Adam is distantly related to Dan's wife who is also from Sălaj. However, disputes often arise between farmers and hired shepherds about standards of care. Grievances are usually dealt with immediately, but not always happily, and hired shepherds do walk away without giving notice. During the research for this study, Nelu, another of Dan's hired shepherds was sent to prison for the attempted manslaughter of a landowner who had attacked Dan's father. The incident happened during the autumn transhumance, at dusk when some of the sheep may have strayed onto an unfenced field of lucerne. Nelu was 18 years old and had worked as a shepherd for six years. Luckily, the landowner survived, and the D family paid for Nelu's defence: he came out of jail after 18 months and returned to the flock. A third hired shepherd, a 14year-old, worked for Dan for three seasons, but just before the start of the spring transhumance, he stole a sheep dog and ran away.

Dan owns 10 or 12 Carpathian sheep dogs (bred for guarding sheep) and several smaller herding dogs, all of which help raise the alarm if predators are about. Otherwise, the shepherds have only their hard wooden staffs and physical strength for protection. Huband et al. (2010) noted that the quality of hired shepherds in their study area has fallen since 1989. This is because few youngsters want such a hard and lonely life; waged shepherding has become a last resort for those who are down on their luck. But a degree of trust is essential on both sides, and the D family makes noticeable efforts to accommodate their workers' needs and tolerate their personalities. They work alongside them, eat with them and provide company and heat in the shieling, as well as food at the end of day and night shifts. 


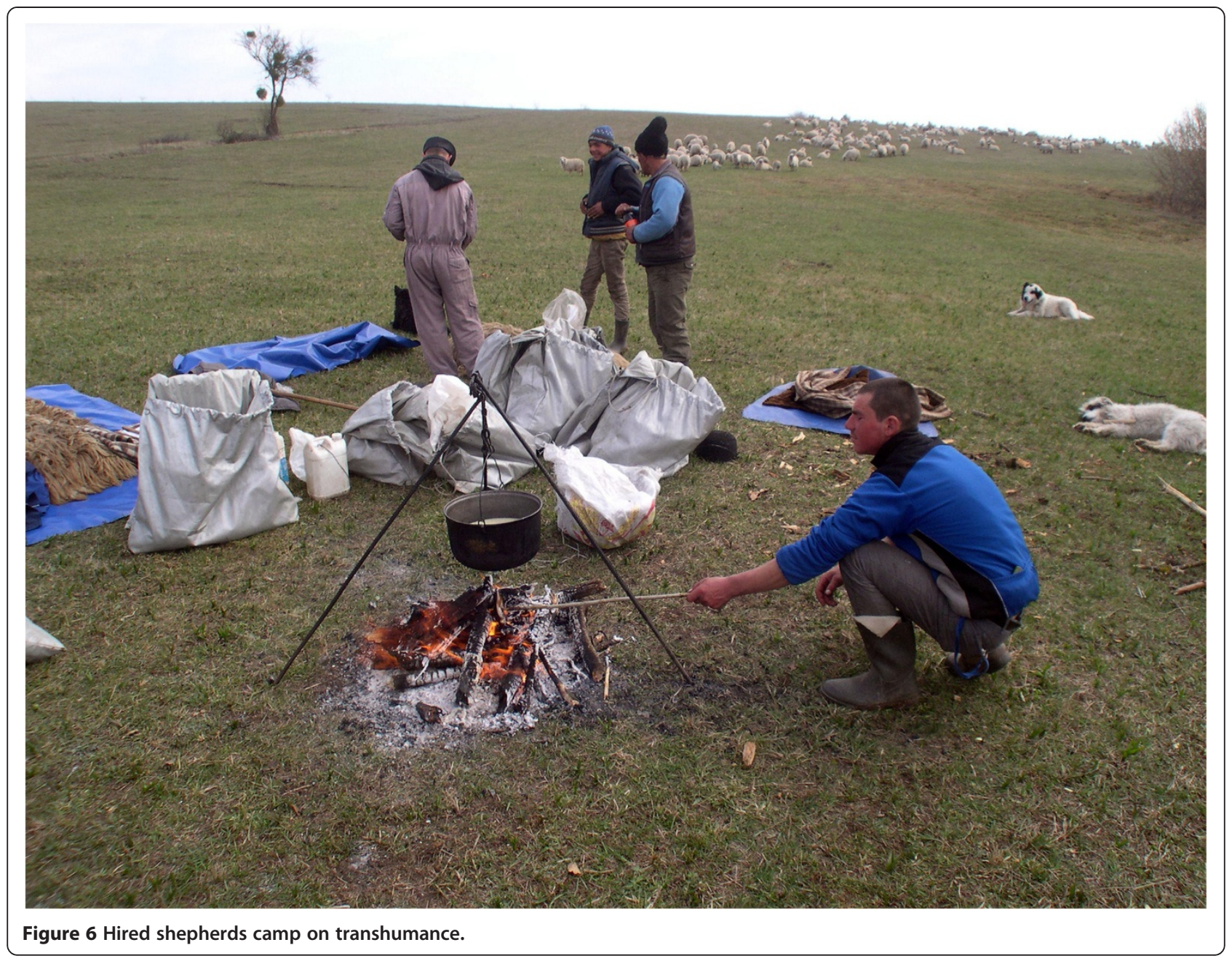

It is a tough life and employees often want to leave before the long-distance walks. Then Dan has to rely on family members, including his wife, and fellow flock masters to go with him. Other long-distance transhumant flocks may be left completely in charge of hired men: in the four cases studied here, all the farmers walked with their animals and spent the majority of the year with them. But since the study began, two of the four have given up long-distance transhumance altogether.

The S family from Rășinari used to walk 600 ewes over the southern Carpathians from their rented mountain ranges to Lugoj, a journey of about $200 \mathrm{~km}$. The family consists of the father, the mother who is in charge of making the cheese, their daughter, who is a teacher, and two sons. Both sons are in their twenties, and both of them want to continue the family business. The family has split their land into two, giving one son his own farm near Lugoj in the milder Banat region. The other son raises sheep and cattle, and they are kept on the same farm all year round. He accommodates his father's sheep during the winter.
In September 2010, the sheep-owner and two hired men walked the ewes to Lugoj for the last time. Close to the end of the three-week journey, they were attacked and beaten by six men, allegedly for allowing their sheep stray onto crops. This was enough to persuade the $\mathrm{S}$ family that it would be better to transport their animals by truck in future: previously, they had sent the sheep and lambs home by lorry in spring, but their fear outweighed their worry about the extra expense.

Two brothers, from Jina, who shared the management of a sheep farm with their widowed mother used to walk their sheep to lower pastures near Deva and remain with them outside all winter. In 2011, during the drought, they decided that it was not worth the trouble any more. They decided to keep their 600-strong flock at home, feeding it on their own hay as well as hay bought from neighbours and maize which they buy from a wholesaler who visits the village.

At the time of writing, the Răşinari farmer Dumitru C and his son Radu are still making long-distance treks with their sheep from Rasinari to Sălaj. Traditionally, 


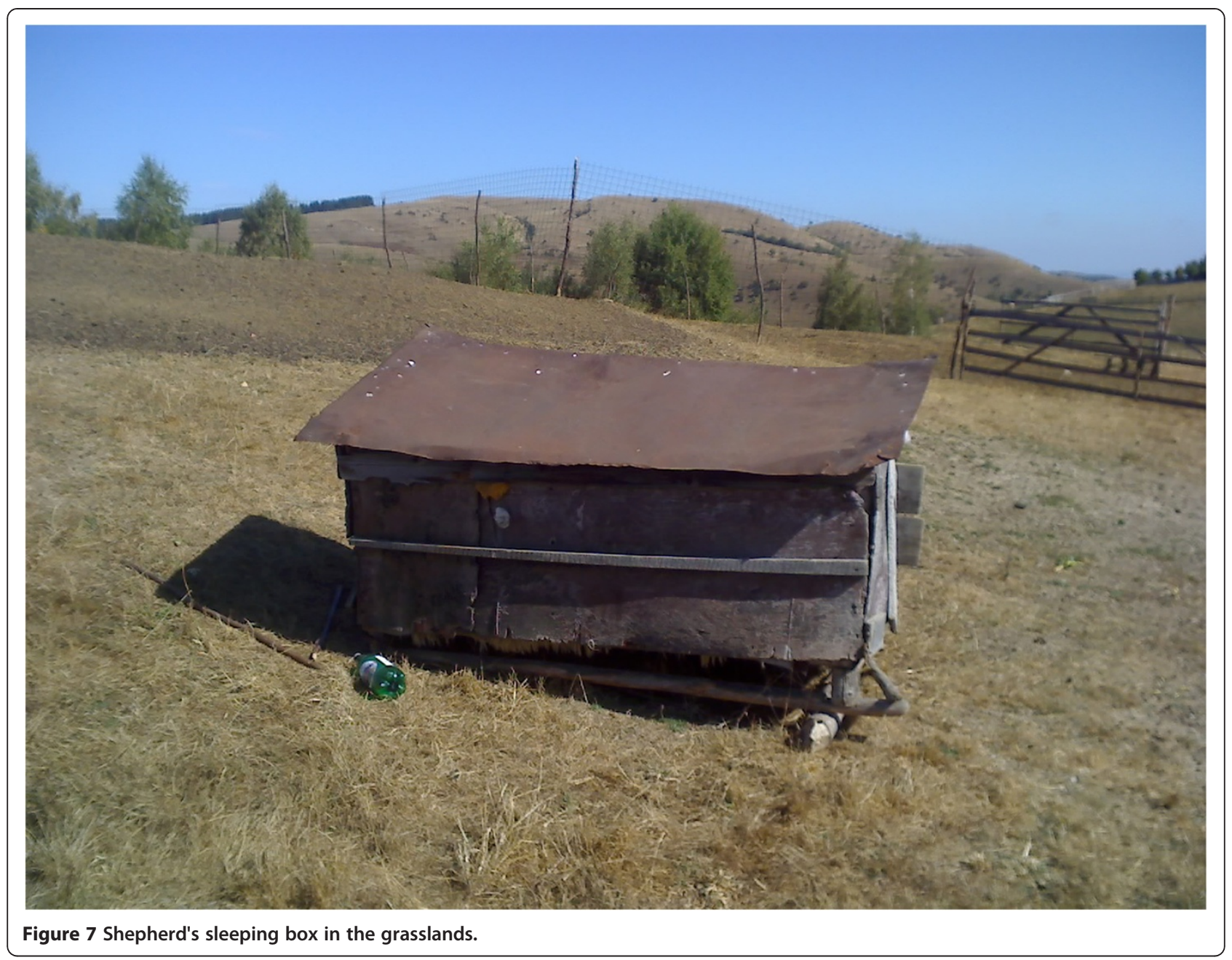

transhumant farmers from this village led their flocks to Dobrogea on Romania's Black Sea coast or south to Wallachia (Figure 2). The C's winter grazing is rented, and they too buy hard feed for their animals in winter, particularly before lambing.

Dumitru $\mathrm{C}$ is in his early sixties. He breeds donkeys as a commercial sideline and usually takes 20 donkeys, 12 dogs, and six or seven hired shepherds to support his flock of 1,200 Țurcana sheep. In summer, he rents mountain grazing from the town hall in Răşinari. Like the other three farmers interviewed for this article, Dumitru $C$ earns about half of his income from selling cheese and the rest from lamb meat. As with Dan's parents, Dumitru, his wife, their son and the hired men (several of whom are fellow villagers with small flocks of their own) all help. They milk the sheep and make the cheese at their summer folds; they fetch the cheese down to the family house by jeep once or twice a week. The $\mathrm{C}$ family sells their cheese at the door, but mostly via agents who take it to Bucharest where sheep's cheese from Mărginimea Sibiului is regarded, and sold, as a regional delicacy.
Asked for his impressions, Dumitru C said that the produce from his transhumant sheep is mai ecologic healthier for people and better for the environment. He notices a difference between his winter grazing in 'the valley' and the mountains: the summer pastures are much cleaner, the water cleaner and the air fresher. But he cannot prove that the market prefers it, and he could not continue to farm without EU hand-outs.

\section{Social and cultural benefits of transhumance}

Through kinship and community ties, there is a strong social element to transhumance. It harks back to the tovaraşire (comradeship) that evolved when flocks were kept communally by groups of friends or villagers, and each owner took his or her turn to look after them and/or do the cheesemaking. (A communal herding system still exists in other parts of Romania.) Asked why they continue to walk with their sheep over long distances, Dan D and Dumitru S said that they do it because they love it, and it is in their blood. 
With some 6,000 souls, some 2,000 of whom are Gypsies, Jina village is a vibrant place. Although youngsters are leaving the land because they can earn more in the cities or abroad, farming, especially sheep rearing, is still the most important economic activity and pastoral traditions play an important role in keeping the community together. In August, some farming families hold parties at their folds to celebrate nedeia, a traditional holiday (formerly also a marriage fair) that marked the time when sheep came down from the highest pastures. It coincides with the feast of the Assumption of the Virgin Mary, one of the most important religious holidays in Romania, and in the nearby village of Tilisca, St. Mary's Day is celebrated as part of a shepherds' festival. Festivalul Oierilor comprises a sheep breeders' meeting, a church service, a feast and an open air folk music concert. There are similar annual song and dance festivals in Jina and other Mărgineni communities and in 'sister' villages over the mountains in Wallachia (founded by Jinari who were fleeing from the Habsburgs for religious motives), all of which are inspired by the area's shepherding culture. Between Christmas and New Year, young shepherds dressed in special, embroidered, long-sleeved sheepskin coats perform regional dances and songs around the village. Religion is taken seriously here too: on Saints' days and at the many weddings, christenings and funerals, the villages' two main Orthodox churches are full.

Pride in their pastoral culture shows in other ways: in 2011, the Asociatia Reuniunea Mărginenilor Sibiului (The Friends of Mărginimea Sibiului) instituted an annual prize for the area's most promising young shepherd. Candidates have to be attending a local school, nominations are made by teachers, priests or mayors, and the award consists of ten lambs.

\section{Transhumance and the environment}

Romania is an outstandingly beautiful country. It is extraordinarily rich in intact natural habitats and the wild animals that live in them (Maanen et al. 2006). Thanks to the inaccessibility of its mountains to heavy machinery, large areas of the country were never collectivised. This allowed a remarkably old-fashioned agricultural system to survive. According to Romania's Institut Național de Statistic, in 2010 just over two million holdings of 1 ha of less were registered for EU subventions. This represented roughly half of the country's total agricultural structures (Ghib 2013). These are the small, extensive, low-impact, mixed, family farms that the European Union dubs subsistence or semi-subsistence. Although large sheep flocks, such as those seen in Mărginimea Sibiului of up to 1,500 head, may cause over-grazing (Buza et al. 2009), transhumant animals do not constitute a monoculture. Their seasonal migrations are an integral part of the mosaic that has kept Romania looking so green. But these old- fashioned systems are vanishing. A host of pressures are destroying its pristine wildernesses. These include the fragmentation of the countryside as more land is enclosed, urban sprawl, mining, road construction, unregulated logging, ill-conceived hydroelectric schemes, and the advent of large, modern, intensive and factory farms.

One argument for encouraging transhumance, whether short- or long-distance, is that grazing herding animals over extensive areas is good for the land. Huband et al. (2010) have outlined some of the benefits of extensive grazing on semi-natural grasslands, particularly areas where traditional farms lie up against mountain wildernesses. They say that sheep, cattle and horses help to reduce tumbledown. Cattle and horses, being heavy and largefooted, can trample and eat tough young trees that encroach on finer plants. Sheep, which feed low to the ground but have no upper teeth, do not tear plants up by the roots and can help preserve areas of wild flowers which feed caterpillars and other insects; the invertebrates then provide nutrition for birds and small mammals. The animals' dung helps to fertilise the soil, and moving them between summer and winter pastures allows grazed areas to recover when the sheep have gone. Travelling sheep help to disperse seeds (the seeds get caught in their fleeces and spread in their dung). Luick (2008, p. 11) says that 'Recent research about conservation strategies for grazed chalk grassland pointed out that the distribution of the seeds and fruits of many plant species is very much related to transport vectors such as the sheep. Since the number of transhumant sheep is permanently declining it is to assume that in the long run this may cause negative effects on the recolonization of sites and the necessary refreshment of seedbanks'. The above only describes a small part of the Carpathians' complex ecosystem, which also relies on large carnivores to control large wild ungulates such as deer.

Agri-environment schemes such as Natura 2000 and EU Habitats Directives are helping to preserve some areas of the Romanian Carpathian Mountains.

Andrew Jones (2010) is a grassland ecologist who worked in the Romanian Carpathians for seven years. He was attached to the Romanian Ministry of Agriculture on an agri-environment scheme. He understands how small, mixed farms and the practice of transhumance have created a mosaic which allows biodiversity to flourish. Jones says that Transylvania's traditional grasslands are a model for other countries, such as the UK, that have already lost their biodiversity. 'Transylvanian systems can help us learn how to preserve our grasslands' (personal communication).

However, Jones's outlook for Romania's future is gloomy, because of the lack of restrictions on foreign investment (personal communication). Dale-Harris (2014) explains:

Over the past decade, almost 1 million hectares of Romania's land have been bought up by foreign 
companies, using legal loopholes left open by the state. As part of Romania's transition from communism to a modern, neoliberal economy, the movement of peasants off the land has been billed by the government as an inevitability, a hitch on the road to becoming a prosperous, western economy. Eventually, the government insists, everything will level out: the old will die off and the young will move away. This, as Achim Irimescu, the former secretary of state for agriculture, puts it, is "the natural solution" to Romania's peasant problem....

Dale-Harris lays blame for this open season at the EU's door:

Poland and Hungary faced the same situation, yet both countries implemented laws that to an extent increase the security of their country's landowners. Their reasons may have been populist and nationalist, but the results of the laws are a stand against the hegemonic policy of the EU and a relative safeguard to their peasants. The Romanian government has no such plan; here the land policy lies directly in line with that of the EU, a policy which can make Romania's powerful very rich, very quickly.

\section{Transhumance and wild animals}

Romania's Carpathians have the largest populations of Europe's rare and endangered species such as bear, wolf and lynx (Beckmann 2001). Wild boar also inhabit Transylvania and they can kill lambs. Although bears, wolves and lynxes rarely penetrate the more populous parts of the Transylvanian plateau, they are present in the lower, rural areas of the plateau and foothills where shepherds in this study take their flocks for winter. Most sheep in Transylvania are grazed on unfenced land and live out in all seasons. As noted above, they need shepherds and guard dogs to protect them.

According to Colin Shaw, a founder member of Romania's Association of Ecotourism, 'Romania still has some 5,000 European brown bear, over 2,500 wolves, and about 1,500 lynx - some $40 \%$ of the European population of all 3 species. These animals survive in these numbers through lack of contact with humans, though continued hunting and poaching is resulting in a gradual decline.' (Shaw n.d.). Of these three large carnivores, the wolf relies heavily on domestic sheep for its food. It is hard to find a balance between the interests of herdsmen and predatory animals that feed on sheep but are deemed precious to the world at large (see also Lescureux and Linnell 2013; Eriksson 2011). In Romania the same conflicts occur: some hunting of bears and wolves is allowed, but otherwise these wild carnivores are legally protected and farmers are not allowed to shoot them if they attack their flocks. Is this an argument for paying sheep farmers to breed flocks for wolves? That may be too radical a solution, but could conservationists and pastoralists cooperate more widely? This journal has aired such issues: see particularly Heikkinen et al. (2011) for how Finland's herders are organised. Singh et al. (2013) outlines an insurance scheme that encourages northern Indian pastoralists to set aside grazing areas for wild herbivores, and so reduce predation on their own animals by snow leopards and wolves.

\section{Conclusions}

The World Initiative for Sustainable Pastoralism (WISP under the International Union for Conservation of Nature), the European Forum on Nature Conservation and Pastoralism (with its identification of High Nature Value farming in poor, mountainous areas and its associated project, PASTORAL 2000-2003), the Spanish Asociación Transhumancia y Naturaleza, and a Polish initiative are a few of the organisations dedicated to promoting transhumance because of its role in nature conservation, environmental health, food quality and cultural traditions.

In 2013, a group of six shepherds from Romania, Poland and Ukraine walked 600 sheep about $1,400 \mathrm{~km}$ from Rotbav near Braşov to Valašsko in the Czech Republic. By retracing a medieval droving route which is known to have existed between these two points since the fourteenth century, Carpathian Sheep Transhumance (2013) highlighted the value of traditional pastoralism in developing the Slow Food Movement. A number of related food, crafts and cultural events were held along the route. However, Gheorghe Câțean, one of the Romanian shepherds concerned, could not identify any great advantages in transhumance other than saying that it is a form of natural selection (because only healthy sheep survive), that it reduces the fat content of the lamb meat and that it is a great adventure for men! (personal communication). More positively, the President of Sibiu's Sheep Farmers' Association assures us that lambs raised on mountain pastures are sought-after for their taste (Lachenal et al. 2014).

To quote Nori and Gemin (2011), the Common Agricultural Policy is supposed to be supporting pastoralism: 'Pastoralism is being increasingly appreciated worldwide as an environmentally friendly practice, which, in the European Union (EU) is valued as particularly important for the protection and the safeguarding of mountainous areas, defined as "Europe's ecological backbone"'. In 2013, the EU announced important changes to its Common Agricultural Policy (CAP). Among them were the aims of supporting the producers rather than the product, distributing funds more fairly and helping environmental initiatives. The Overview's introduction states:

rural development will continue to play a pivotal role in achieving the CAPs environmental objectives and in 
combating climate change. The focus of the second pillar on sustainability is clearly visible by the fact that at least 30\% of the budget of each Rural Development programme must be reserved for voluntary measures that are beneficial for the environment and climate change. These include agri-environmental-climate measures, organic farming, Areas of Natural Constraints (ANC), Natura 2000 areas, forestry measures and investments which are beneficial for the environment or climate. All these measures contribute significantly to environmental enhancement and climate change because they are adapted to local needs (European Union 2013, p. 7).

This study has found that Romanian sheep farmers are still practising long-distance transhumance because they believe that it is beneficial to their animals, the environment and their produce. They also do it because they love it. But some are pessimistic about its future. As Huband et al. (2010) pointed out, pendulation may be the only way forward, but even that is under threat. The PASTORAL project suggests links between pastoralism and tourism as well as environmental conservation and the preservation of 'public goods' (PASTORAL 2000-2003). More proof is needed that naturally produced meat and milk - and wool for that matter - are not only superior in quality to industrially produced foods but also economically viable and attractive to consumers. Although the PASTORAL project made an excellent start, conservationists and policy-makers still need to talk to, and understand, small, practising farmers, and vice versa.

More needs to be done to persuade the Romanian authorities - and people - to stop deploring the țărani, the smallholders and country people known pejoratively in English as 'peasants', and to start seeing them as a huge, intelligent, dynamic resource. Valuing transhumance, and its contribution to environmental and nature conservation, as well as to the economy and society, lies within this larger context.

\section{Endnote}

${ }^{a}$ The only reference this study has found to such a law comes in the following email from the rural development agency (DADR) in Alba county (neighbouring Dan's home county of Sibiu), dated June 2010: 'With reference to the transportation of sheep across county boundaries, you must contact the local authorities to clarify if you must pay a tax and how much it is.'

\section{Competing interests}

The author declares that she has no competing interests.

\section{Author's information}

$\mathrm{CJ}$ is a writer and artist with a long-standing interest in Romania. She is the author of Blue Guide Romania, Searching for Sarmizegetusa and National Geographic Traveller: Romania. She has been studying Romanian transhumance and sheep farming since 2007. Details about this and her other activities can be found on her website, www.mamaliga.co.uk, and her blog, Carpathian Sheep Walk.

\section{Acknowledgements}

Professor Gheorghe Pavelescu, Dr. Amalia Pavelescu, lleana Morariu, Dragoş Lumpan, Dr. Jean Blăjan, Toma Lupaş, Nicolae Stan Petruțiu and the Martin family.

Received: 28 October 2013 Accepted: 27 February 2014

Published: 25 Mar 2014

\section{References}

Akeroyd, John. 2006. The historic countryside of the Saxon villages of southern Transylvania. Saschiz: Fundația Adept.

Akeroyd, John. 2007. John Akeroyd on Transylvanian natural heritage. Part 1. Film by Raul Cazan, Slow Food Bucharest. http://www.youtube.com/watch? $\mathrm{v}=\_$Gq0Mk3GX2A. Accessed 14 February 2014.

Arnold, Elizabeth R, and Haskel J. Greenfield. 2006. The Origins of Transhumant Pastoralism in Temperate Southeastern Europe: a zooarchaeological perspective from the Central Balkans. British Archaeological Reports International Series 1538.

Beckmann, Andreas. 2001. Crying wolf. Central Europe Review. vol, 3, no 14, 23 April. http://www.ce-review.org/01/14/beckmann14_1.html. Accessed 18 Feb 2014.

Boia, Lucian. 2001. Romania: borderland of Europe. London: Reaktion Books. Buza, Mircea, Marioara Cojocariu-Costea, and David Turnock. 2009. Mărginenii Sibiului. The historical geography of a Transylvanian Carpathian community. Geographica Pannonica 13(4): 137-158.

Carpathian Sheep Transhumance. 2013. www.redykkarpacki.pl. Accessed 18 Feb 2014.

Coman, Mihai. 1996. Bestiarul Mitologic Românesc. Bucharest: Editura Fundației Culturale Române.

Dale-Harris, Luke. 2014. Romania's peasants: standing in the way of foreign investors making a lot of money. 19 February. http://www.theguardian.com/ commentisfree/2014/feb/19/romania-peasants-land-market-local-farmingeconomy.

Deletant, Dennis. 2010. Review of lordachi, Constantin; Dobrincu, Dorin (eds), Transforming peasants, property and power: The collectivization of agriculture in Romania, 1949-1962 and Mungiu-Pippidi, Alina, A tale of two villages: Coerced modernization in the East European countryside. HABSBURG, H-Net Reviews. October. http://www.h-net.org/reviews/showrev.php?id=31092. Accessed 18 Feb 2014.

Densuşianu, Nicolae. 1913. Dacia Preistorică. 2 vols. Bucharest: Institutul de Arte Grafice Carol Oöbl.

Eriksson, Camilla. 2011. What is traditional pastoral farming? The politics of heritage and 'real values' in Swedish summer farms (fäbodbruk). Pastoralism research, policy and practice. http://www.pastoralismjournal.com/content/1/ $1 / 25$.

Europe Regional Yearbook. 2013. Statistical atlas. http://ec.europa.eu/eurostat/ statistical-atlas/gis/viewer). Accessed 18 Feb 2014.

European Union Overview of CAP Reform 2014-2020. 2013. Agricultural Policy Perspectives Brief. No 5. December. http://ec.europa.eu/agriculture/policyperspectives/policy-briefs/05_en.pdf.

Eurostats. 2012. Sheep and goat numbers. http://ec.europa.eu/agriculture/ statistics/agricultural/2012/pdf/d17-0-417_en.pdf. Accessed 18 Feb 2014.

Ghib, Marie-Luce. 2013. Agriculture, agriculteurs et emplois agricoles en Romanie: les enjeux d'une définition. Demeter 13: 77-96.

Grecu, Victor V (ed). 1990. Săliştea Sibiului străveche vatră Românească. Sibiu: Associațiunea Transilvana pentru Literatura Româna si Cultura Poporului Român (Astra).

Heikkinen, Hannu I., Simo Sarkki, and Mark Nuttall. 2011. Users or producers of ecosystem services? A scenario exercise for integrating conservation and reindeer herding in northeast Finland. Pastoralism: Research, Policy and Practice 2012, 2: 11. http://www.pastoralismjournal.com/content/2/1/11. doi:10.1186/2041-7136-2-11. http://literatur.ti.bund.de/digbib_extern/ dn052242.pdf.

Huband, Sally, David I. McCracken, and Annette Mertens. 2010. Long and shortdistance transhumant pastoralism in Romania: past and present drivers of change. Pastoralism 1(1): 55-71.

Hybu Cig Cymru. Meat Production Wales. 2008. The current trends in breeding ewe numbers and meat production within the EU. http://www.hccmpw.org.uk/ 
medialibrary/publications/Sheep\%20industry\%20in\%20the\%20EU\%5B1\%5D. pdf. Accessed 18 Feb 2014.

\|lişiu, E, S. Dărăban, R. Radu, I. Pădeanu, V.-C. Iişiu, C. Pascal, and G. Rahmann. 2013. The Romanian Tsigai sheep breed, their potential and the challenges for research.

Jones, Andrew. 2010. Ghosts in our grasslands. Lessons from abroad - a look at management of grasslands in Transylvania. British Wildlife 21. nr 5, June Landbauforsch. Appl Agric Forestry Res 2(63): 161-170. DOl:10.3220/ LBF_2013_161-170.

Juler, Caroline. 2009. Blue guide: Romania, Special reprint edition. London: Somerset Books.

Lachenal, Pierre, Frédérique Lorenzi and Amalia Pavelescu. 2014. Protection des terres agricoles en montagne et valorisation des parcours et prairies d'altitude - Bilan et perspectives. Forthcoming paper for Le foncier agricole Usages, tensions et régulations. Lyons, 11-12 June.

Lescureux, Nicolas, and D. John C. Linnell. 2013. The effect of rapid social changes during post-communist transition on perceptions of the human wolf relationships in Macedonia and Kyrgyzstan. Pastoralism: Research, Policy and Practice. http://www.pastoralismjournal.com/content/3/1/4

Luick, Rainer. 2008. Transhumance in Germany. European Forum on Nature Conservation and Pastoralism. http://www.efncp.org/download/ Swabian_Alb_F_F_Download.pdf. Accessed 18 Feb 2014

Lupaş, Toma, Nicolae Stan Petruțiu, Nicolae Jianu, Alexandra Achim, Sora Calugărițoiu, loan Muntean, Pantelimon Muntean, Simona Apolzan, Zoe Dragomir, D.A. Dădârlat, loan Dârdea, Nicolae Şchiopu, Ana Alexa, loan luga, Ioan Nan, Ioan Mihu, and Mihai Nistor. 2009. Oierii mărgineni în Crimeea şi Sudul Rusiei. Sibiu: Editura Salgo.

Maanen, Erwin van, Roger Klaver, Wibe Altenburg, George Predoiu, Marius Popa, Ovidiu lonescu, Ramon Jurj, Serban Negus, Georgeta Ionescu, and Michael Soulé. 2006. Safeguarding the Romanian Carpathian Network: a vision for large carnivores and biodiversity in Eastern Europe. http://www.altwym.nl/ uploads/file/77Safeguarding\%20the\%20Romanian\%20Carpathian\% 20ecological\%20network.PDF. Accessed 18 Februrary 2014.

MAPDR. 2007. UE nu interzice transhumanta. Fermierul. 5 February. Translated from the Romanian original. http://www.fermierul.ro/modules.php? name $=$ News\&file $=$ article\&sid $=1239$.

Nandriş, John G. 1985. The Stîna and the Katun: Foundations of a research design in European Highland Zone Ethnoarchaeology. World Archaeology 17(2): 256-268

Nori, Silvia, and Michele Gemini. 2011. The Common Agricultural Policy vis-à-vis European pastoralists: Principles and practice. Pastoralism: Research, Policy and Practice 1: 27. doi:10.1186/2041-7136-1-27. http://www.pastoralismjournal. com/content/1/1/27.

PASTORAL. 2000-2003. European forum on nature conservation and pastoralism. http://mp.mountaintrip.eu/index.php?id=4\&tx_mdtlmountaintrip_pi1 [uid] $=121$.

PASTORAL 2. 2001. The impact of scale and accession on biodiversity value. PASTORAL: the agricultural, ecological and socio-economic importance of extensive livestock systems. Report of the $2^{\text {nd }}$ workshop of the PASTORAL project. Romania: Moieciu de Sus. October. http://mp.mountaintrip.eu/uploads/ media/conferenceworkshopdocs/pastoral_cwd2.pdf.

Pearson, Michael. 2012. The discordant accord: Romania and the European Union. University of Kent. Unpublished doctoral thesis.

PFLA. Pasture Fed Livestock Association. 2011. http://www.pfla.org.uk. Accessed 18 Feb 2014

Rancourt, M. de, and L. Carrère. 2011. Milk sheep production systems in Europe: Diversity and main trends. In Economic, social and environmental sustainability in sheep and goat production systems, ed. A. Bernués, J.P. Boutonnet, I. Casasús, M. Chentouf, D. Gabiña, M. Joy, A. López-Francos, P. Morand-Fehr, and F. Pacheco, 107-111. Zaragoza: CIHEAM/FAO/CITA-DGA. Options Méditerranéennes. Série A. Séminaires Méditerranéens; n. 100). 7. Proceedings of the International Seminar of the Sub-Network on Production Systems of the FAO-CIHEAM Inter-Regional Cooperative Research and Development Network on Sheep and Goats, 2010/11/10-12, Zaragoza (Spain). http://om.ciheam.org/om/pdf/a100/00801490.pdf. Accessed 18 February 2014

Ryder, Michael L. 1983. Sheep and man. London: Duckworth Publishers.

Shaw, Colin. http://www.roving-romania.co.uk/Pages/Wildlife.html. Accessed 20 Feb 2014.

Singh, Navinder J., Yash Veer Bhatnagar, Nicolas Lecomte, Joseph L. Fox, and Nigel G. Yoccoz. 2013. No longer tracking greenery in high altitudes: Pastoral practices of Rupshu nomads and their implications for biodiversity conservation. Pastoralism: Research, Policy and Practice 3: 16. doi:10.1186/ 2041-7136-3-16. http://www.pastoralismjournal.com/content/3/1/16. Slow Food Turda. http://slowfoodturda.ro/site/.

Thorpe, Nick. 2007. EU clash with Romanian tradition. 27 January. http://news. bbc.co.uk/1/hi/programmes/from_our_own_correspondent/6303371.stm. Accessed 18 Feb 2014.

Totoianu, Radu. 2010. Păstoritul satelor de pe Valea și din Munții Sebeșului. Sibiu: Universitatea Lucian Blaga. Unpublished doctoral thesis.

Verdery, Katherine. 1994. The elasticity of land: Problems of property restitution in Transylvania. Slavic Review 53, no. 4 (Winter 1994): 1071-1109.

\subsection{6/2041-7136-4-4}

Cite this article as: Juler: După coada oilor: long-distance transhumance and its survival in Romania. Pastoralism: Research, Policy and Practice 2014, 4:4

\section{Submit your manuscript to a SpringerOpen ${ }^{\odot}$ journal and benefit from:}

- Convenient online submission

- Rigorous peer review

- Immediate publication on acceptance

- Open access: articles freely available online

- High visibility within the field

- Retaining the copyright to your article

Submit your next manuscript at $\gg$ springeropen.com 